DOI https://doi.org/10.18551/rjoas.2017-12.01

\title{
THE EFFECT OF PRODUCTS, PRICE AND SERVICE QUALITY ON CUSTOMER SATISFACTION IN "RICE FOR THE POORS" PROGRAM
}

\author{
Surip Ngadino*, Pawirosumarto Suharno, Liestijati Farida \\ University of Mercu Buana, Jakarta, Indonesia \\ *E-mail: dinosurip@gmail.com
}

\begin{abstract}
This study aimed to determine and analyze the partial influence of product variables, price, and service quality on consumer satisfaction in Indonesian government's "Rice for the Poors" ("Beras Miskin", abbreviated as "Raskin") program, as well as the influence of product variable, price, and service quality simultaneously to customer satisfaction in the program. The sampling method used is proportionate stratified random sampling. The research is conducted in West Bandung regency, Jawa Barat (West Java) Province with a population of 86.908 RTS-PM, and data collection was conducted in October 2015. The method of analysis used in this research is the analysis of correlation and linear regression. The results of the study conclude that the variable of product, price, and quality of service simultaneously or partially possess positive and significant effect on consumer satisfaction in Raskin program. The service quality is one of the strong variables that influence the consumer satisfaction, followed by price and product variables.
\end{abstract}

\section{KEY WORDS}

Service quality, consumer, satisfaction, raskin program.

One of the national government programs on direct social assistance program aimed at the community is providing subsidized rice for poor families (called as Beras Miskin, abbreviated as "Raskin"). The program is implemented under the coordination of the Coordinating Ministry for Human Empowerment and Culture (Kemenkopmk), Ministry of Social Affairs (Kemensos), National Team for Acceleration of Poverty Reduction (TNP2K), Ministry of Home Affairs (Kemendagri) and BULOG. The subsidized rice program for the poor family is aimed at reducing the burden of poor household expenditure (RTM) as part of fulfilling basic food needs in the form of rice. Thus, the program is also intended to improve poor family access in the fulfillment of basic food needs as one of the basic rights of the community. This is one of the central and regional government programs that are important in improving national food security. Based on General Guidelines (Pedum) on Raskin stated that rice distributed is medium grade and is in good condition, pest free, and $15 \mathrm{~kg}$ per RTSPM every month quantum. Its' Raskin Price Redeem (HTR) set at IDR 1,600.00 per kilogram. The Raskin program has been running for at least 15 years and every year the Government sets the Household Beneficiary Beneficiary Targets (RTS - PM) which in recent years refers to the 2011 Social Protection Data Collection (PPLS) and is a market or consumer market for BULOG.

BULOG is a public company under the Ministry of State-Owned EntelDRrises (BUMN) based on Government Regulation No.7 of 2003 dated January 10, 2005, with the intent of carrying out quality logistics business that is qualified and adequate for the fulfillment of the livelihood of the public. In certain cases, BULOG carries out certain tasks that are given regarding basic food prices security, managing Government Food Reserves and distribution of basic food to certain segments of society, especially staple foods in the form of rice and other basic food stipulated by the Government in food security framework. BULOG performs a government assignment by conducting a series of activities in the form of rice physical procurement, physical storage and maintenance, physical distribution, and managing Raskin physical distribution, in other words, BULOG has implemented Raskin program in accordance with general guidelines, technical guidance and applicable implementing guidance. Nevertheless, in reality from monitoring results in online and print media, short 
message service (SMS) from Raskin complaints, and other sources in the last 5 years there was complaints from RTS-PM in some villages, sub-districts, and districts throughout Indonesia which complaint mainly regarding rice quality and quantum.

Based on the preliminary analysis of Raskin Complaint, it can be seen that the number of RTS-PM complaints in 2010 - 2014 has increased at municipality/regency level. It indicates that the complaint needs to receive attention from BULOG. Said rice condition is generally referred to as unfavorable rice conditions such as unfit for consumption, musty, yellow, or brownish, powdery, and having less than $15 \mathrm{~kg}$ per sack in quantity.

Furthermore, based on a preliminary analysis of the Number of Grievances at the Provincial Level in the last 5 years $(2010-2014)$, it was noted that the areas with the highest complaints over the last 2 years were in Java and from 5 provinces in Java. East Java province received the highest number of Complaints coming from 8 and 9 villages/districts/ Regency. West Java had complaints coming from 9 and 7 villages/districts / Regency as exhibited in table 2. The complaints have been clarified by the management.

Similar to the implementation of other government policies and programs in general, the distribution of rice to the community has experienced a number of problems and challenges in the process. Common problems encountered in relation to the distribution of rice include the delivery of Raskin not according to the scheduled distribution schedule. This occurred for various reasons. Based on the type of complaints and general problems mentioned above, it can be grouped into product factors (rice conditions such as unfit for consumption, musty odor, pale, yellow or brown, powdery / floury, and rice quantum less than $15 \mathrm{Kg}$ per sack), price factor (the price set does not match the price in the field), and service factor (distribution at night without prior confirmation).

A number of complaints indicate consumer dissatisfaction (RTS-PM) on the implementation of Raskin Program. Therefore it is vital BULOG to understand consumer behavior, in order to implement development strategy on the product, price, and service quality in Raskin program. Faced with the situation, BULOG as State-Owned EnteIDRrise (BUMN) was given instruction to perform as operator and supplier of subsidized rice. They must give special attention and appropriate strategy to the problem occurred. If it is allowed to continue and receive less attention, it is possible that Raskin Program is not implemented in accordance with existing guidelines. In order Raskin Program to succeed, BULOG ought to choose an appropriate strategy to increase the realization of rice distribution annually. On the basis of identification of the above problems, this research attempts to answer the following problems:

- Does the product affect customer satisfaction?

- Does the price affect customer satisfaction?

- Does the quality of service affect customer satisfaction?

- Do the product, price, and quality of service together affect customer satisfaction?

\section{LITERATURE REVIEW}

Product. Product is the most fundamental variable of marketing. A wide range of products are marketed make consumers compare the price and quality of a product with another. Therefore, it is necessary to employ a strategy that includes product characteristics and form, brand and service policy. Tjiptono (2008) states that product is everything that a manufacturer can offer to be noticed, requested, sought, bought, used, or consumed by the market to fulfill relevant markets needs or wants. Based on its level, according to Kotler (2005) product can be divided into five levels described as follows:

- The core product, which offers the main benefits and uses that consumer's need.

- Generic products, reflecting the basic function of a product.

- Expected product, is a set of attributes and conditions that are expected when consumers buy a product.

- Additional products, providing additional services and benefits that differentiate the company's offerings 
- The potential product, every addition, and transformation to the product that may be done in the future.

Based on eight dimensions of product quality according to Stevenson (2005: 386), product variables dimensions relevant to this research are as follows:

- Compatibility to specification (conformance to specification). Conformance is the conformity of product performance with the stated standard of a product. This could be considered a "promise" that the product must meet. Products possessing this dimension's quality mean it is according to the standard.

- The beauty (aesthetics). The beauty of product display that can attract consumers. This is often done in the form of product design or packaging. Some brands update their "face/display" to be more beautiful in the eyes of consumers.

Price. According to Stanton (2005: 22), price is a sum of money (possibly with the addition of goods) required to obtain some combination of an accompanying product and service. There are several factors that affect pricing, which is described as follows:

- Internal factors, consisting of company's marketing objectives, organizational considerations, marketing objectives, marketing strategy mix, and cost.

- External factors, consisting of market situation and demand, competition, intermediary expectations, and environmental factors such as socioeconomic conditions, government policies and regulations, culture, and politics.

There are basically four types of pricing objectives, one of which is: price stabilization, conducted by fixing prices to maintain a stable relationship between the price of an entelDRrise and the price of the industry leader. The pulDRose of pricing services should be translated into a service pricing program by considering factors such as cost and other consideration factors, such as the political and legal environment, the international environment, and the price element in other marketing programs.

Based on several theories and explanations above, price indicator (Stanton, 2005: 308), consists of the following.

- Price Compliance with product and service quality:

Price is often used as a quality indicator for consumers. For example, expensive goods or services tend to be assumed for possessing good quality. The price level of one service to another of the same kind sometimes differs, which is based on the factors causing it. The price consumers expect for a service is equivalent to results of the services offered.

- Compatibility:

Price level is affordable for people's purchasing power. Compatibility is related to how the consumer will pay for the services to be purchased. Usually in cash and credit, depending on the organization's policy.

Based on the results of the above theoretical study, obtained dimensions of price variables in accordance with this study are the suitability of the price with product value and affordable price appropriateness compared to society's purchasing power level.

Service Quality. The quality of service is the level of excellence expected and control over the level of excellence to meet consumer desires, Tjiptono (2007). Parasuraman et al. (2008: 64), also states that attributes that can be used to evaluate service quality can be seen from five basic dimensions, which are described as follows:

- Physical/Tangible (Tangibles), i.e the ability of a company to show its existence to external parties. Appearances and capabilities of reliable corporate physical facilities and infrastructure to the surrounding environment are clear evidence of the services provided by the service provider. This includes physical facilities (e.g buildings, warehouses, etc.), equipment and equipment used (technology), and the appearance of employees.

- Reliability, namely the ability of the company to provide services in accordance with the promised accurately and reliably. Performance must be in accordance with consumer expectations which means punctuality, equal service for all consumers without error, sympathetic attitude, and with high accuracy. 
- Responsiveness, which is a policy to help and provide services quickly (responsive) and appropriate to consumers, with clear information delivery. Letting consumers wait caused negative perceptions in service quality.

- Guarantees and certainty (Assurance), namely knowledge, politeness, and the ability of company employees to nurture consumer confidence to the company. This includes several components including communication, credibility, security, competence, and courtesy.

- Empathy, which provides a sincere and personal attention given to consumers by trying to understand consumer desires. Where a company is expected to have understanding and knowledge about consumers, understand the specific needs of consumers, and have a convenient operating time for consumers.

According to Tse and Wilton (in Tjiptono, 2005), consumer satisfaction or dissatisfaction is the consumer's response to perceived mismatch evaluation between previous expectations and actual product performance after its use. According to Hawkins and Lonney quoted in Tjiptono (2004: 101) the attributes of satisfaction shaping consist of: Expectations conformity, Revisit Interest and Recommendation Willingness. Expectations conformity is the level of conformity between product performance expected and perceived by consumers, including: obtained products are in accordance or exceeded expectation; employee services are in accordance or exceeded expectation; and supporting facilities are in accordance or exceed expectation.

Fardiani (2013) set the indicator as described below to measure customer satisfaction:

- No complaints from customers of the service or products to Dyriana Bakery \& Café Pandanaran, Semarang City.

- Convenience felt by the customer at the time of purchase at Dyriana Bakery \& Café Pandanaran, Semarang City.

- Fulfillment of wishes and expectations of customers when making a purchase at Dyriana Bakery \& Café Pandanaran, Semarang City.

- Loyal customers and provide good references of the product to others.

Based on the description above, mind frame and hypothesis is exhibited as in Figure 1.

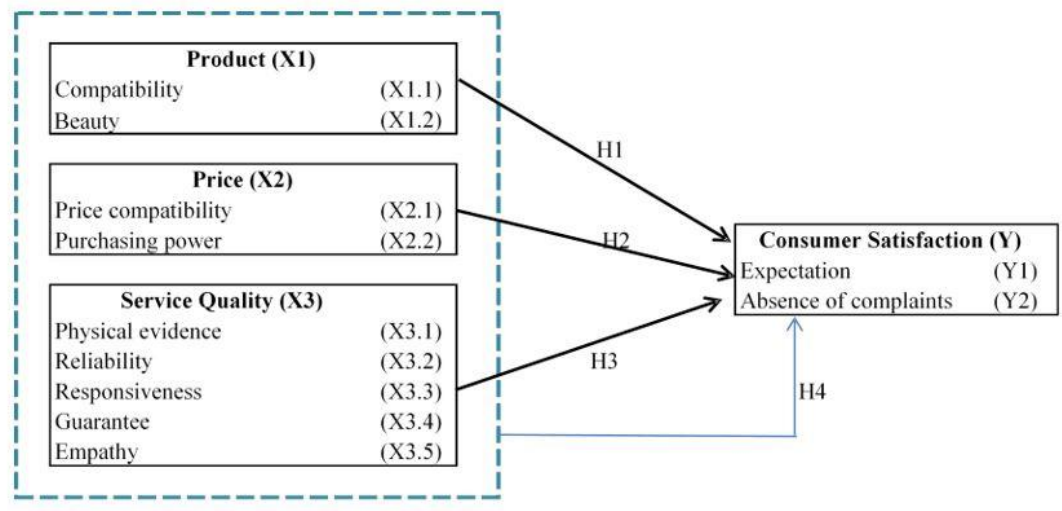

Figure 1 - Mind Frame

The dependent variable is variable that affects or becomes the result due to their independent variables. In this case, the dependent variable is Customer Satisfaction $(Y)$. The independent variables (Product (X1), Price (X2) and Service Quality (X3)) are the variables that influence or become the cause of the change or emerging dependent variable. Thus, the hypothesis in this study is described as follows:

$\mathrm{H}_{1}$ : Product Variable affects Consumer Satisfaction

$\mathrm{H}_{2}$ : Price Variable affects Consumer Satisfaction

$\mathrm{H}_{3}$ : Variable Service Quality affects Consumer Satisfaction

$\mathrm{H}_{4}$ : Variables of product quality, price, and quality of service affect the Consumer Satisfaction in Raskin Program. 


\section{METHODS OF RESEARCH}

The population in this study was Household Target Beneficiary Targets (RTS-PM) in 2015. RTS-PM was Raskin target consumer of 2015 which amounted to 86,908 RTS in West Bandung Regency, Jawa Barat (West Java) Province, Indonesia. Sampling was carried out with consideration of the limitations that do not allow the entire population to be studied. To determine some samples required, formula utilized was in accordance to Rao Purba in Martanti (2006), which is described as follows:

$$
\mathrm{N}=\mathrm{Z} / 4(\mathrm{Moe})^{2}
$$

Note:

$\mathrm{N}=$ total sample

$Z=$ The normal distribution level is at a significant level $5 \%=1,96$

Moe $=$ Margin of error maximal errors that can be corrected, set at $10 \%$ or 0,10 .

By using Moe at $10 \%$, it was determined that minimum total sample could be taken are 96 respondents. To complete and refine this research, the researchers took a sample of 200 people. Data collection technique utilized in this research is Questionnaire and Proportionate Stratified Random Sampling.

\section{RESULTS OF STUDY}

The results of data processing indicate that the background of the majority of respondents are as follows: aged over 51 years (34.9\%), has no permanent job, or originated from housewives background (45\%), income between IDR 401,000 - IDR 750,000/month $(32 \%)$, and recipients of long-term subsidized rice between $5-10$ years (35\%). The summary of respondents' response to the statement of all research variables are as follows:

- Regarding indicators on the conformity of specifications and product appearance, the majority of respondents are not satisfied with product quality, while they are generally satisfied with product quantum.

- Regarding price conformity indicator with product value, in general, respondents are satisfied without affected by product condition or prices. This is possible because the value and benefits of rice as a staple food has not been replaced by other food products.

- Regarding 5 indicators of service quality variables (physical form, reliability, assurance, responsiveness, empathy), the majority of respondents feel satisfied.

- Regarding conformity to expectations indicators, the majority of respondents are not satisfied with product condition, because it is not in line with expectations. In contrast, respondents are generally satisfied with product price and service quality because it is in line with their expectations. While the indicator receives no complaints from consumers, the majority of respondents are not satisfied product condition, therefore there are more consumers who complain about product condition. The majority of respondents are satisfied with product price and service quality, therefore few consumers complain about them.

The results of validity test on the questionnaire of product variables, price, service quality, and customer satisfaction indicate that all items of statement/instrument are valid. The calculation results from all $r$ value $>r$ table equal to 0.138 . On the other hand, reliability test analysis result using Cronbach's Alpha model illustrates that the statement on the questionnaire related to product variables, price, service quality, and overall customer satisfaction are reliable with the $\alpha$ count value $0.873>\alpha$ table of 0.060 . 
Table 1 - Multiple Linear Regression Analysis

\begin{tabular}{|c|c|c|c|c|c|c|c|c|}
\hline & \multirow{2}{*}{ Model } & \multicolumn{2}{|c|}{$\begin{array}{c}\text { Unstandardized } \\
\text { Coefficients }\end{array}$} & \multirow{2}{*}{$\begin{array}{c}\begin{array}{c}\text { Standardized } \\
\text { Coefficients }\end{array} \\
\text { Beta }\end{array}$} & \multirow[t]{2}{*}{$t$} & \multirow{2}{*}{ Sig. } & \multicolumn{2}{|c|}{ Collinearity Statistics } \\
\hline & & $\mathrm{B}$ & Std. Error & & & & Tolerance & VIF \\
\hline \multirow{4}{*}{1} & (Constant) & -2.008 & 1.691 & & -1.188 & .236 & & \\
\hline & Product & .181 & .036 & .258 & 5.028 & .000 & .865 & 1.156 \\
\hline & Price & .208 & .034 & .325 & 6.107 & .000 & .802 & 1.246 \\
\hline & Service Quality & .259 & .036 & .400 & 7.137 & .000 & .722 & 1.385 \\
\hline
\end{tabular}

Dependent Variable: Consumer Satisfaction

From the result of regression analysis, the regression equation obtained is as follows:

$$
Y=-2,008+0.181 X 1+0.208 X 2+0.259 \times 3
$$

The regression model can be interpreted as follows:

The constant $(\alpha)$ is the negative value of -2.008 when the product $(X 1)$, price (X2), and service quality (X3) value is 1 . This indicates that the consumer is not satisfied with the product, price and service quality. Therefore it is necessary to immediately make improvements to these three variables.

$ß 1=0.181$ if product variable $(\mathrm{X} 1)$ is increased with the assumption of price variable (X2) and service quality (X3) is considered fixed, hence consumer satisfaction will also increase equal to 0.181 .

$\beta 2=0.208$ if the price variable is increased with the assumption that product variable (X1) and service quality (X3) are considered fixed, any increase in price variable (X2) then consumer satisfaction will increase by 0.208 . This indicates the need for improved rice conditions and adjusted to community purchasing power to adjust the opportunity for price increases.

$B 3=0.259$ if service quality variable is increased with product variable assumption (X1) and price (X2) is considered fixed, hence consumer satisfaction will increase equal to 0.259. Based on the value of regression coefficient (ß) of the three independent variables, it is known that service quality variables have the most dominant influence on consumer satisfaction at 0.259 . This indicates that the priority scale of BULOG policy in increasing consumer satisfaction should be more focused on improving service quality, price, and product variables. This is also based on the fact that BULOG is easier to mobilize internal resources in managing service aspect, for example in storage management policy, maintenance, distribution, and human resources. Prices and products are more influenced by external factors such as government intervention in purchasing price policy of government (HPP), season condition and rice harvest schedule in Indonesia.

In order to satisfy the consumer, the minimum value for the service quality variable is 7 . If this is included in the equation, the following formula will be obtained:

$$
\begin{gathered}
Y=-2.008+0.181+0.208+(0.259 \times 7) \\
Y=0.194
\end{gathered}
$$

To determine whether product, price, and service quality variables partially affect consumer satisfaction, in table 1 . each variable t value is significant 0.000 <probability 0.05 . It means $\mathrm{H} 1$ was accepted or product variable, price variable, and services quality variable partially provide a significant effect on customer satisfaction. On the other hand, based on the SPSS calculation, $t_{\text {count }}$ compared to $t$ value on $t$ distribution table with $\alpha=5 \%, t_{\text {table }}$ value of 1.652 was obtained. The result is described as follows:

$t_{\text {count }}$ value for product variable is 5.028 . Because $t_{\text {count }}(5.028)>t_{\text {table }}(1.652)$ then $H 0$ is rejected and $\mathrm{H} 1$ accepted, it means that product variable partially gives significant influence to consumer satisfaction. 
$t_{\text {count }}$ value for price variable equal to 6.107. Because $t_{\text {count }}(6.107)>t_{\text {table }}(1.652)$ then $H 0$ is rejected and $\mathrm{H} 1$ accepted, it means that price variable partially gives significant influence to consumer satisfaction.

$t_{\text {count }}$ value for service quality variable equal to 7.137 . Because $t_{\text {count }}(7.137)>t_{\text {tabel }}$ (1.652) then $\mathrm{HO}$ is rejected and $\mathrm{H} 1$ accepted, it means that service quality variable partially gives significant influence to consumer satisfaction.

$\mathrm{F}$ test was conducted to determine whether the independent variable simultaneously affects consumer satisfaction.

Table 2 - F Test Result

ANOVA

\begin{tabular}{ccccccc}
\hline & Model & Sum of Squares & $\mathrm{df}$ & Mean Square & $\mathrm{F}$ & Sig. \\
\hline & Regression & 807.576 & 3 & 269.192 & 81.530 & $.000^{\mathrm{b}}$ \\
1 & Residual & 647.144 & 196 & 3.302 & & \\
& Total & 1454.720 & 199 & & & \\
\hline
\end{tabular}

a. Dependent Variable: Satisfaction

b. Predictors: (Constant), Service, Product, Price

Based on Table 2, it can be concluded that $F$ is significant $(0,000)<$ probability 0.05 . SPSS calculation result obtained $F_{\text {count }}$ equal to 81.530 , because $F_{\text {count }}$ value $>F_{\text {table }}(81.530>$ 2.65). Consequently, $\mathrm{HO}$ is rejected and $\mathrm{H} 1$ is accepted. Thus it is evident that there is a significant influence of product, price and service quality simultaneously to customer satisfaction.

The above test results answered the hypothesis of this study as described in Table 3.

Table 3 - Hypothesis Examination Result

\begin{tabular}{lll}
\hline & \multicolumn{1}{c}{ Hypothesis } & Conclusion \\
\hline H1 & Product Variables have a positive effect on customer satisfaction & Hypothesis accepted \\
\hline H2 & Price variables have a positive effect on customer satisfaction & Hypothesis accepted \\
\hline H3 & Service Quality Variables have positive effect on consumer satisfaction & Hypothesis accepted \\
\hline H4 & $\begin{array}{l}\text { Product Variables, Price, Quality of Service together have a positive effect on } \\
\text { customer satisfaction }\end{array}$ & Hypothesis accepted
\end{tabular}

The coefficient of determination is the ability of the independent variable to contribute to the dependent variable in percentage units.

Table 4 - Coefficient of Determination Examination Result

Model Summary

\begin{tabular}{ccccc}
\hline Model & $\mathrm{R}$ & $\mathrm{R}$ Square & Adjusted R Square & Std. Error of the Estimate \\
\hline 1 & $.745^{\mathrm{a}}$ & .555 & .548 & 1.81707 \\
\hline
\end{tabular}

Based on table 4, it could be interpreted that R2 (coefficient of determination) $=0.548$ or $54.8 \%$. It means the ability of independent variables (i.e product, price, and quality of service) in explaining customer satisfaction is equal to $54.8 \%$ while the rest of $45.2 \%$ illustrates the presence of other free variations not observed in this study.

Correlation Analysis of Research Interdependent Dimensions. This analysis was conducted to measure the correlation between free and bounded dimensions using the Pearson Correlation matrix and SPSS program.

Based on the results of dimension correlation analysis between research variables, moderate relationship strength level was obtained which are described as follows:

- Product variable dimension to consumer satisfaction variable dimension:

The dimension of beauty/display (X1.2) on product variables has a close relationship with the conformity on expectation dimension (Y1) on consumer satisfaction variable with a correlation coefficient of 0.467 medium strength level. Pest free, odorless, and non- 
imperative look, easy to assess the subsidized rice, compared and tailored to the expectations of the consumers themselves. This exhibits a dominant relationship between rice display dimension and consumer suitability dimension.

- Dimension on price variable to dimension on customer satisfaction variable:

Product value dimension (X2.1) on price variable has a close relation with no complaints dimension (Y1.2) on consumer satisfaction variable with a correlation coefficient of 0.403 moderate strength level. Price compliance with products value obtained by consumers is very largely perceived by them as well. This exhibits rice value can not be replaced by other products. The prevailing HTR is cheaper compared to the price of similar rice in the public market, therefore consumers have no complaints against the subsidized rice price at IDR $1,600,00 / \mathrm{kg}$.

Table 5 - Interval Dimension Correlation Matrix

\begin{tabular}{|c|c|c|c|}
\hline \multirow[t]{2}{*}{ Variable } & Variable & \multicolumn{2}{|l|}{ Y (Consumer Satisfaction) } \\
\hline & Dimension & Comformity to Expectation & No Complaints \\
\hline \multirow{2}{*}{$\begin{array}{l}\text { X1 } \\
\text { Product }\end{array}$} & Comformity to specification & 0,307 & 0,185 \\
\hline & Display & 0,467 & 0,392 \\
\hline \multirow{2}{*}{$\begin{array}{l}\mathrm{X} 2 \\
\text { Price }\end{array}$} & Product Value & 0,255 & 0,408 \\
\hline & Society Purchase Power & 0,310 & 0,499 \\
\hline \multirow{5}{*}{$\begin{array}{l}\text { X3 } \\
\text { Service Quality }\end{array}$} & Tangibles & 0,480 & 0,535 \\
\hline & Reliability & 0,474 & 0,206 \\
\hline & Responsive & 0,434 & 0,120 \\
\hline & Guarantee & 0,482 & 0,404 \\
\hline & Empathy & 0,445 & 0,195 \\
\hline
\end{tabular}

Source: Processed Primary Data, 2015.

The dimension of people's purchasing power (X2.2) on the price variable has a close relationship with no complaints dimension (Y1.2) on customer satisfaction variable with a correlation coefficient of 0.499 medium strength level. Consumers who generally earn below UMR rates, are mostly elderly and have no permanent job. Therefore possessing low purchasing power of RTS-PM. RTS-PM has no choice but to consume subsidized rice. Thus no complaints from consumers against product price at IDR 1,600,00/kg.

Both products value and purchasing power dimensions possess dominant relationship no complaint dimension.

- Dimension on service quality variable to customer satisfaction variable dimension:

Tangibles dimension (X3.1) on service quality variables has a close relationship with the conformity of expectation ( $\mathrm{Y} 1.1)$ and no complaints dimensions (Y1.2) on customer satisfaction variables with a correlation coefficient of 0.480 and 0.535 moderate strength levels. Service quality in the form of the availability of weighing equipment, service schedule, unpaid rice stock at the Distribution Point, and adequate rice stock to supply Raskin program affected the consumers. They tend not to complain about the lack of basic staple food supply for the family, information on delivery schedule, and rice storage at the Point of Contribution. Those factors live up to consumer expectation.

The dimension of reliability (X3.2) on service quality variables have a close relationship with conformity expectations dimension (Y1) on consumer satisfaction with a correlation coefficient of 0.474 moderate strength levels. The subsidized rice carrier/bodyguard participates in maintaining security and responsible for goods delivery (condition and quantity of rice). The officer is willing to be contacted if there are complaints from subsidized rice recipients. This is according to consumer expectations and provides satisfaction to consumers.

The responsive dimension (X3.3) on the service quality variables has a close relationship with the conformity of expectation dimension (Y1.1) on customer satisfaction variable with a correlation coefficient of 0.434 moderate strength level. Consumer confidence (RTS) on rice received after purchasing subsidized rice is responsive, such as the officer is 
ready to inform RTS when necessary, responds to RTS complaints and ready to replace poor condition rice or those with less weight in a sack. This indicates the responsiveness of the officer to provide comfort as per customer expectations.

The dimension of guarantee (X3.4) on service quality variables has a close relationship with conformity expectations (Y1.1) and no complaints dimension (Y1.2) on customer satisfaction variables with a correlation coefficient of 0.482 and 0.404 respectively moderate strength level. Guarantees on products in the form of fixed price, smooth monthly rice delivery, the availability of workers during rice unloading gives comfort and adhere to expectations therefore consumers do not file complaint.

The dimension of empathy/attitude (X3.5) on service quality variables has a close relationship with the conformity of expectations dimension (Y1.1) on customer satisfaction variables with a correlation coefficient of 0.445 with moderate strength level. The officers have a caring attitude in dealing with complaints. Similarly, the procedure of complaint service is easy and fast, providing convenience and satisfaction according to consumer expectations.

\section{DISCUSSION OF RESULTS}

Research result exhibits three independent variables of product, price, and service quality had a significant influence on subsidized rice consumer satisfaction distributed by BULOG in Raskin Program. Each variable is described as follows:

The Influence of Products on Consumer Satisfaction. $\mathrm{H} 1$ hypothesis shows a positive and significant effect of product variables on consumer satisfaction in Raskin program. Similarly with the results of regression analysis is a positive value coefficient means a positive influence between the products with customer satisfaction. These results indicate that a good assessment of the product is capable of satisfying consumer's needs, and vice versa. In addition, consumer experience in buying and consuming subsidized rice will result in an assessment of customer satisfaction. If the product can satisfy the consumer then the consumer will provide a positive assessment of the product. The findings are consistent with research conducted by Rosita (2006), Windoyo (2009), Donny (2009), Harjanto (2010), Asghar et al (2011) Budi (2012), Julius (2014) and Siti et al (2015), which stated that the product had a positive and significant impact on customer satisfaction.

Based on responses of respondents to the statement of all research variables known in general, respondents are not satisfied with product condition. The condition of rice is influenced by internal factors that are under BULOG control (Controllable Factor) and external factors that are outside BULOG's control (Uncontrollable Factor). To overcome rice conditions and domestic rice absorption target, BULOG must improve management in rice physical procurement, storage, and physical maintenance, and physical distribution in the following ways.

First of all, during internal physical procurement stage of rice, BULOG is suggested to perform the following actions:

- Conducting a mapping of potential harvests throughout Indonesia.

- Undertaking coaching to partners throughout Indonesia to ensure rice is properly delivered to BULOG.

- Enhancing grain procurement units (stages) in the regions through cooperation with various farmer groups throughout Indonesia.

- Improving existing infrastructure and strengthening infrastructure lease cooperation with second parties. Cooperation with BULOG partners must be equipped with several administrative requirements, including production capability, data on grain purchases from farmers, farmers' locations, and land area.

- Recruiting employees, employ educational and training programs to overcome obstacles on inadequate quantity and quality of human resources on duty in the field, especially procurement officers and supervisory / inspection officers on grain / rice quality. 
- Establishing a standardized quality inspection process before produce enter the warehouse and stored in BULOG, aiming to deliver good rice quality in the hands of the beneficiaries. So far, there have been several cases that caused BULOG to receive complaints about the quality of rice distributed for Raskin's, which are unfit for consumption or in bad quality. To tighten rice quality entering the warehouse, there is need of standardization for the quality inspection process. Rice submitted by partners' parties should be checked by a special team, in a closed private room, so that there is no direct contact/communication and collusion with goods owners. During this time, the rice inspector should be posted in the warehouse, allowing goods owner to meet directly with the inspector. With the standardization of the quality inspection process, every case can be evaluated. Its origin, suppliers, and condition.

- Rice can not go in and out of BULOG warehouse from one area to another. If one place/warehouse rice can not enter the warehouse because it does not meet the standards, then the rice will not be able to enter another warehouse in Indonesia, Rice stored in a warehouse are packed in $15 \mathrm{~kg}$ sack solely for the pulDRose of distribution in two months time, the rest is packed in $50 \mathrm{Kg}$ sacks. Should large quantity of rice are packed in $15 \mathrm{~kg}$ sacks, it would be difficult to control and accountable for its quality.

Secondly, efforts could be undertaken on maintaining external factors are as follows.

- Proposed application of flexibility on Government Purchase Price (HPP) and Basic Price (HD) of rice and grain as the lowest price applicable at farmer to government levels. Applying HPP flexibility is conducted in order to adjust to the price of grain and rice at farmers level. Determining HD will also optimize the absolDRtion of farmers rice during harvest because BULOG may buy above the basic price (HD), but not less than HPP.

- Rice harvest will simultaneously affect the condition of BULOG rice supply. During harvest, rice supply becomes abundant, then the price goes down, vice versa. BULOG is considered to be losing important momentum in the procurement of rice on a large scale during harvest season should HPP is not adjusted. Should the government set the purchase price of rice higher than the current HPP at IDR. 7,300 per kilogram during the rainy season harvest period, the BULOG warehouse would be filled with more rice in good condition.

- Another factor outside the control is the weather. During the rainy season, rice production will be abundant and prices will fall, and vice versa.

Thirdly, at the stage of storage and physical treatment of rice, the following actions should be taken into account.

- Treatment of rice on a regular basis in the form of spraying and fumigation so that the rice does not get infected by pest during distribution.

- Before the rice is distributed, it should be reprocessed again in order to clean the dirt (i.e rocks), then packed in $15 \mathrm{~kg}$ sacks.

- Setting up drier to maintain rice condition, especially during rainy season.

- Improving physical condition of rice warehouse, with the aim of controlling warehouse temperature to maintain stored rice quality; ensuring there's no leak in the warehouse, to store rice in a safe condition and maintained its quality; keeping birds and mice from entering storage area, in order to deter them from piercing the rice sacks and reduce rice quantum.

Finally, at the stage of physical distribution, efforts that can be done include improvement of monitoring and supervision management including applying strict penalty to transportation service companies appointed as the carrier in Raskin distribution, should they not implement the provisions in accordance with agreements. For instance:

- Ban violation on the use of ganco in loading and unloading rice sacks from and into distribution trucks;

- Violation against an obligatory use of tarpaulin cover over truckloads to keep rainwater from rice sacks; 
- Violation on the total truck crew allowed.

Price Influence On Consumer Satisfaction. H2 hypothesis exhibits a positive and significant effect of price on customer satisfaction in Raskin program. These results indicate that the price determined will be influenced by the consumers' purchasing power, which ultimately satisfies consumers' needs. At the time of the purchase transaction, the consumer will compare product price with other existing similar product. If the product conforms to consumers purchasing power and possesses desired product specification which will satisfy the consumer.

Similarly, the results of regression analysis is a positive value coefficient means a positive influence between price and customer satisfaction. This means that consumers will choose a product with a relatively low price. In this study, consumers considered that the Raskin program subsidizes rice at affordable prices for RTS-PM and is below the general market price of IDR1,600 / kg with a share of $15 \mathrm{~kg} / \mathrm{month}$.

The findings of this study is in accordance with research conducted by Rosita (2006), Riky (2009), Aurimas (2009), Ryan (2010), Muhammad (2012) and Julius (2014), which states that prices have a positive and significant impact on customer satisfaction. Moreover, it is also in line with Kottler and Armstrong (2005) that the sum of the value traded by consumers worth the benefits of owning or using the product or service.

The result of respondent's analysis on the product value indicator, willingness and society purchasing power from the price dimension in this research, and based on the fact that Raskin Rice Price (HTR) was set IDR. 1,600 by the government Government in accordance with public purchasing power has been in effect for 7 years since 2008, indicating an opportunity for the proposed adjustment of the Raskin Price Redeem (HTR) which is still affordable for beneficiary purchasing power along with the improvement of product condition and service quality.

Service quality influence on Consumer Satisfaction. H3 states that service quality has a positive and significant impact on customer satisfaction in Raskin program. Therefore it can be concluded that Hypothesis 3 is accepted. This means consumers consider service quality set by BULOG is in accordance with consumers perception. Therefore it can increase consumer satisfaction in Raskin Program.

The findings of this study is in line with research conducted by Riky (2009), Mohammad (2009), Riyan (2010), Rahim (2010), Ariane (2011), Donny (2011), Asghar (2011), Budi (2012), Muhammad (2012), Siti (2015) and Ahmad (2015). Moreover, Adhiyanto (2012) states that the existence of good service quality within a company will create satisfaction for its customers. Once the customer is satisfied with the product or service it receives, the customer will compare the services provided by other similar companies. In this case, the quality of service performed by BULOG in supporting Raskin program can not be compared with other companies because BULOG is the only company engaged in food logistics and obtained public services assignment in distributing subsidized rice.

However, to improve customer satisfaction, BULOG needs to improve service quality, among others, including:

- Improving cooperation with other land transportation service companies, in addition to existing transport service companies, in an effort to increase the availability of truck fleets to distribute Raskin on time.

- Encouraging cooperation with land transport service company to implement all provisions of rice delivery from BULOG warehouse to distribution point (TD) in accordance with set requirements, to ensure Raskin distribution is in accordance with the schedule. Violations of these provisions will reduce the level of Raskin service.

- The addition of organic employees in the field, namely guards to directly supervise the delivery of subsidized rice to the distribution point in an effort to control, guarantee and account for the quality and quantum of subsidized rice to the beneficiary community.

Influence of Product, Price, and Service Quality to Customer Satisfaction. H4 states that product, price, service quality simultaneously affect the customer satisfaction in Raskin program. Based on the calculation result, $F_{\text {count }}$ for this construct $=81.530\left(F_{\text {count }}>2,65\right)$, so it 
can be concluded that Hypothesis 4 is accepted. This result can be intelDRreted that rice medium managed by BULOG, pricing, and service quality has a positive effect on consumer satisfaction simultaneously.

\section{CONCLUSION}

The product has a partial significant effect on customer satisfaction. If the Product gets better, then the satisfaction will increase. The display dimension has a dominant relationship with the conformity of expectations.

Price affects partially significant to customer satisfaction. If the price is better, then the consumer satisfaction will increase. Price, product values, and purchasing power dimensions have a dominant relationship with no complaints dimension.

Service Quality is a partially significant influence on consumer satisfaction. If the quality of service is better, then consumer satisfaction will increase. The dimensions of tangibles and assurance have a dominant relationship with conformity and no complaints dimensions.

The product, price, and service quality have significant effect simultaneously to customer satisfaction equal to $54.8 \%$, while the rest are influenced by another independent variable not observed in this research.

\section{REFERENCES}

1. Adhiyanto, M. (2012). Analisis Pengaruh Kualitas Pelayanan Terhadap Kepuasan Pelanggan Menggunakan Jasa Balai Latihan Kerja Industri (Blki) Semarang. Unpublished Undergraduate Thesis. Fakultas Ekonomi Universitas Diponegoro.

2. Al-Tit, A.A. (2015). The Effect of Service and Food Quality on Customer Satisfaction and Hence Customer Retention. Asian Social Science, Vol. 11, No. 23; 2015.

3. Akbar, M.M. \& Parvez, N. (2009). Impact of service quality, trust, and customer Satisfaction on customers loyalty. ABAC Journal. (Vol 29, No. 1)

4. Ariane C.N.T. (2011). Analisis Pengaruh Faktor Teknologi, Kualitas Layanan dan Fokus Pelanggan Terhadap Kepuasaan Pelanggan (Studi pada Pembeli Produk Bandeng Elrina di Semarang). Unpublished Undergraduate Thesis. Universitas Diponegoro.

5. Budi Prihartono (2012). Analisis Pengaruh Produk, Pelayanan dan Distribusi Terhadap Kepuasan Pelanggan Pada PT. Nayati Indonesia Semarang. Q-Man (Vol. 2 No.3)

6. Dapkevičius, A. \& Melnikas, B. (2009). Influence Of Price And Quality To Customer Satisfaction: Neuromarketing Approach. Science - Furture of Lithuania/Mokslas Lietuvos Ateitis. (Vol. 1, no. 3).

7. Fardiani, A.N. (2013). Analisis Pengaruh Kualitas Pelayanan, Harga, Dan Promosi Terhadap Kepuasan pelanggan Dyriana Bakery \& Café Pandanaran Semarang. Unpublished Undergraduate Thesis. Universitas Diponegoro.

8. Harjanto, R.N. (2010). Analisis Pengaruh Harga, Produk, Kebersihan Dan Kualitas Layanan Terhadap Kepuasan Pelanggan. Unpublished Thesis. Universitas Diponegoro.

9. Jahanshahi, A.A., Gashti, M.A.H., Mirdamadi, S.A., Nawaser, K., Khaksar, S.M.S. (2011). Study the Effects of Customer Service and Product Quality on Customer Satisfaction and Loyalty. Internasional Journal of Humanities and Social Science, Vol.1, no.7.

10. Kurniawan, J.H. (2014). Analisa Pengaruh Marketing Mix terhadap Keputusan Pembelian Compressed Natural Gas (CNG) Pada Perusahaan-Perusahaan Industri Sejabodetabek. Unpublished Graduate Thesis. Universitas Mercu Buana.

11. Kotler, P. \& Armstrong. (2005). Manajemen Pemasaran. Jilid 1. PT.Index kelompok Gramedia, Jakarta.

12. Martanti, A.D.F. (2006). Analisis Strategi Differensiasi, Promosi, Dan Kualitas Layanan Dalam Meningkatkan Minat Beli. Unpublished Undergratuate Thesis. Universitas Mercubuana, Jakarta.

13. Malik, M.I., Ghafoor, M.M., Iqbal, H.K. (2012). Impact of Brand Image, Service Quality and price on customer satisfaction in Pakistan Telecommunication sector. Internasional Journal of Business and Sosial Science, Vol. 3, no. 23. 
14. Mosahab, R., Mahamad, O., Ramayah, T. (2010). Service Quality, Customer Satisfaction and Loyalty: A Test of Mediation. Internasional Business Research, Vol. 3, No. 4.

15. Parasuraman, A., Zeithaml, V.A. dan Berry, L.L. (2008). Delivering Quality Service: Balancing Customer Perceptions and Exxpections. NY: The Free Press.

16. Wuryandari, R. (2006). Pengaruh Harga, Produk, dan DistribusiTerhadap Kepuasan Konsumen Pada Jasa PT. Kereta Api ( Persero ) DAOP IV Semarang. Unpublished Thesis. Universitas Diponegoro.

17. Sugiyono (2010). Metode Penelitian Kuantitatif Kualitatif \& RND. Bandung: Alfabeta

18. Stanton, W. (2005). Manajemen Pemasaran. PT. Gramedia Pustaka Utama, Jakarta.

19. Stevenson, W.J. (2005). Operations Management. 8th ed.McGraw-Hill, hal. 386.

20. Tjiptono, F. (2004). Manajemen Jasa. Penerbit Andi. Edisi Kedua : Yogyakarta.

21. Tjiptono, F. (2005). Prinsip-Prinsip Total Quality Service, C.V. Andi Offset, Yogyakarta.

22. Tjiptono, F. (2007). Pemasaran Jasa. Malang: Bayumedia Publishing.

23. Tjiptono, F. (2008). Strategi Pemasaran. Edisi III. Yogyakarta: Penerbit Andi.

24. Windoyo, R.F. (2009). Analisis Pengaruh Kualitas Pelayanan, Kualitas Produk, Persepsi Harga, dan Lokasi Terhadap Kepuasan Konsumen (Studi Kasus pada Waroeng Steak \& Shake Semarang). Unpublished Undergraduate Thesis. Universitas Diponegoro.

25. Yana, D. (2009). Pengaruh kualitas produk dan kualitas pelayanan terhadap kepuasan serta loyalitas pelanggan pada PT. Masterwood Indonesia. Unpublished Graduate Thesis. Universitas Indonusa Esa Unggul. 